\title{
PENGARUH KEBIJAKAN HUTANG, PROFITABILITAS DAN UKURAN PERUSAHAAN TERHADAP NILAI PERUSAHAAN PADA PERUSAHAAN MANUFAKTUR SUB SEKTOR FOOD AND BEVERAGE YANG TERDAFTAR DI BEI TAHUN 2011 - 2015
}

\author{
Rohmah \\ Alumni Program Studi Akuntansi S1 \\ Sekolah Tinggi Ilmu Ekonomi Bisnis Indonesia, Jakarta \\ dan \\ Nur Aida \\ Dosen STIE Bisnsi Indonesia, Jakarta
}

\begin{abstract}
The purpose of this study to determine the effect of debt policy, profitability and firm size on the value of the company in manufacturing companies food and beverage sub-sector in the Indonesia Stock Exchange in 2011-2015. The independent variables tested were debt policy, profitability, firm size and corporate value. The sample of the study was 10 companies with purposive sampling method. This study uses data in the form of financial statements and annual reports of companies obtained from the Ind

onesia Stock Exchange. The data were analyzed by using multiple linear regression analysis with EViews version 9 program. The test result proved that debt to equity ratio had no effect on firm value $(P B V)$. Return on assets has significant and negative effect on firm value (PBV). Size has significant and negative effect on company value (PBV).
\end{abstract}

Keywords: debt policy, profitability, firm size and firm value

\begin{abstract}
Abstrak: Tujuan penelitian ini untuk mengetahui pengaruh kebijakan hutang, profitabilitas dan ukuran perusahaan terhadap nilai perusahaan pada perusahaan manufaktur sub sektor food and beverage di Bursa Efek Indonesia tahun 2011-2015. Variabel bebas yang diujikan adalah kebijakan hutang, profitabilitas, ukuran perusahaan dan nilai perusahaan.. Sampel penelitian berjumlah 10 perusahaan dengan metode purpossive sampling. Penelitian ini menggunakan data berupa laporan keuangan dan laporan tahunan perusahaan yang diperoleh dari Bursa Efek Indonesia. Data dianalisis menggunakan teknik analisis regresi linier berganda dengan program EViews versi 9. Hasil pengujian membuktikan bahwa debt to equity ratio tidak berpengaruh terhadap nilai perusahaan (PBV). Return on assets berpengaruh secara signifikan dan negatif terhadap nilai perusahaan (PBV). Size berpengaruh secara signifikan dan negatif terhadap nilai perusahaan (PBV).

Kata Kunci: kebijakan hutang, profitabilitas, ukuran perusahaan dan nilai perusahaan
\end{abstract}




\section{Pendahuluan}

Bursa Efek Indonesia (BEI) merupakan wadah bagi para investor dan emiten. Bagi para investor BEI merupakan tempat menanamkan modalnya, untuk itu laporan keuangan merupakan sumber informasi bagi investor sebagai dasar pertimbangan dalam pengambilan keputusan investasi di pasar modal. Hal ini mendorong masing-masing perusahaan untuk melakukan berbagai inovasi dan strategi bisnis agar terhindar dari kebangkrutan. Perusahaan manufaktur merupakan perusahaan yang sangat komplek, karena didalam perusahaan manufaktur tidak hanya menjual tetapi juga memproduksi barang tersebut. Sehingga bagi perusahaan manufaktur yang memiliki tingkat operasional tinggi akan membutuhkan dana yang lebih, untuk memenuhi kekurangan dana tersebut perusahaan membutuhkan pihak ketiga dalam pemenuhan pendanaannya. Untuk mendapatkan kepercayaan dari pihak-pihak ketiga atau investor maka perusahaan harus selalu menjaga nilai perusahaan dalam keadaan baik. Tujuan perusahaan berusaha mendapatkan profit yang maksimal sehingga nilai perusahaan direfleksikan dengan harga sahamnya dipasar modal akan meningkat.

Harga saham mencerminkan semua informasi baru, sumber informasi tersebut dapat diperoleh dengan menganalisis laporan keuangan suatu perusahaan tersebut. Nilai perusahaan dapat menggambarkan keadaan perusahaan. Menurut Sartono (2011) nilai perusahaan yaitu tujuan memaksimumkan kemakmuran pemegang saham ditempuh dengan memaksimumkan nilai sekarang atau present value, Semua keuntungan pemegang saham akan meningkat apabila harga saham yang dimiliki meningkat. Dengan baiknya nilai perusahaan maka perusahaan akan dipandang baik oleh para calon investor, demikian pula sebaliknya. Ketika pemegang saham mempercayakan pengelolaan kepada pihak lain, para pemilik mengharapkan pihak manajemen 3 akan berjuang sekuat tenaga untuk meningkatkan nilai perusahaan, yang akhirnya akan meningkatkan nilai kemakmuran pemegang saham. Indikator yang biasanya digunakan oleh para investor adalah dengan memperhatikan kebijakan hutang, profitabilitas dan ukuran perusahaan.

Debt to Equity Ratio (DER) adalah rasio yang menggambarkan perbandingkan hutang terhadap modal dalam pendanaan perusahaan dan menunjukan kemampuan modal sendiri perusahaan tersebut untuk memenuhi seluruh kewajibannya. Jika perusahaan memiliki profitabilitas yang tinggi maka sahamnya akan diminati oleh para investor. Profitabilitas merupakan kemampuan suatu perusahaan untuk mendapatkan laba (keuntungan) dalam suatu periode tertentu. Return On Assets (ROA) merupakan salah satu rasio profitabilitas, dalam rasio keuangan rasio ini sering disoroti karena mampu menunjukan keberhasilan perusahaan dalam menghasilkan keuntungan. Menurut Sutrisno (2012), Return On Assets (ROA) merupakan ukuran kemampuan perusahaan dan menghasilkan laba dengan semua aktiva yang dimiliki oleh perusahaan. Rasio laba bersih terhadap total aktiva mengukur pengembalian atas total aktiva setelah bunga dan pajak. Semakin besar nilai $R O A$, hal ini menunjukan bahwa nilai perusahaan semakin baik pula karena tingkat pengembalian investasi semakin besar. Ukuran perusahaan (size) juga dianggap mampu mempengaruhi nilai perusahaan. Karena semakin besar ukuran atau skala perusahaan maka akan semakin mudah pula perusahaan akan memperoleh sumber pendanaan baik bersifat internal maupun eksternal. Dalam penelitian ini nilai perusahaan diukur dengan Price to Book Value $(P B V)$, yang merupakan perbandingan harga pasar dari suatu saham dengan nilai buku ( bookvalue).

\section{Landasan Teori}

\subsection{Akuntansi dan Manajemen Keuangan}

Akuntansi adalah bahasa bisnis, setiap organisasi menggunakannya sebagai bahasa komunikasi saat berbisnis ( Susanto, 2013). Sedangkan menurut Sutrisno (2012), manajemen keuangan yaitu semua aktivitas perusahaan yang berhubungan dengan usaha-usaha mendapatkan dana perusahaan dengan biaya yang murah serta usaha untuk menggunakan dan mengalokasikan dana tersebut secara efisien. Dalam arti lain manajemen keuangan (financial management) juga dapat diartikan sebagai suatu 
kegiatan perencanaan, penganggaran, pemeriksaan, pengelolaan, pengendalian, pencarian dan penyimpanan dana yang dimiliki oleh organisasi atau perusahaan.

\subsubsection{Laporan Keuangan}

Menurut Munawir (2012) Laporan keuangan merupakan alat yang sangat penting untuk memperoleh informasi sehubungan dengan posisi keuangan dan hasil-hasil yang telah dicapai oleh perusahaan yang bersangkutan. Laporan keuangan yang dibuat oleh perusahaan terdiri dari beberapa jenis, tergantung dari maksud dan tujuan pembuatan laporan keuangan. Masing-masing laporan keuangan memiliki arti sendiri dalam melihat kondisi keuangan perusahaan, baik sebagian, maupun secara keseluruhan. Menurut Kasmir (2012) dalam praktiknya, secara umum ada 5 (lima) jenis laporan keuangan yang biasa disusun, yaitu: Neraca (balance sheet), Laporan Laba Rugi (Income Statement), Laporan Perubahan Modal, Laporan Arus Kas dan Laporan Catatan Atas Laporan Keuangan. Pihak yang memakai laporan keuangan beserta kegunaannya anatara lain Investor, Kreditor (pemberi pinjaman), Pemasok, Shareholders, Pelanggan, Pemerintah, Karyawan dan Masyarakat.

\subsection{Hutang}

Pengertiang hutang menurut Manduh (2010), hutang didefinisikan sebagai pengorbanan ekonomis yang mungkin timbul dimasa mendatang dari kewajiban organisasi sekarang untuk mentransfer aset atau memberikan jasa ke pihak lain dimasa mendatang, sebagai akibat transaksi atau kejadian dimasa lalu. dalam hutang ada kebijakan yang harus dijalankan menurut Sukrini (2012), kebijakan hutang merupakan kebijakan yang menentukan seberapa besar kebutuhan dana perusahaan dibiayai oleh hutang. Dalam penelitian ini untuk menghitung kebijakan hutang penulis menggunakan rasio DER (Debt to Equity Ratio). Menurut Sawir (2013), debt to equity ratio adalah rasio yang menggambarkan perbandingan hutang terhadap modal dalam pendanaan perusahan dan menunjukan kemapuan modal sendiri perusahaan tersebut untuk memenuhi seluruh kewajibannya.

$$
\text { Debt to Equity Ratio }=\frac{\text { Total Hutang }}{\text { Modal }}
$$

\subsection{Profitabilitas}

Menurut Niresh dan Velnampy (2014), profitabilitas adalah sejumlah uang perusahaan yang dapat dihasilkan dari sumber daya apapun yang dimiliki perusahaan. Karena tujuan akhir dari setiap perusahaan adalah memaksimalkan profitabilitas. Sedangkan menurut Fahmi (2012), rasio profitabilitas digunakan untuk mengukur efektivitas. Namun dalam penelitian ini rasio yang digunakan adalah Return On Assets (ROA). Menurut Sutrisno (2012), return on assets (ROA) merupakan ukuran kemampuan perusahaan dan menghasilkan laba dengan Semua aktiva yang dimiliki oleh perusahaan. Sedangkan menurut Kasmir (2012), Return On Assets (ROA) adalah rasio yang menunjukan hasil (return) atas jumlah aktiva yang digunakan dalam perusahaan. Selain itu, $R O A$ memberikan ukuran yang lebih baik atas profitabilitas perusahaan karena menunjukan efektivitas manajemen dalam menggunakan aktiva untuk memperoleh pendapatan.

$$
\text { Return On Assets }(R O A)=\frac{\text { Laba Setelah Pajak }}{\text { Jumlah Aktiva }}
$$


ukuran perusahaan adalah faktor utama untuk menentukan profitabilitas dari suatu perusahaan dengan konsep yang biasa dikenal dengan skala ekonomi. Maksudnya skala ekonomi menunjuk kepada keuntungan biaya rendah yang didapat oleh perusahaan besar karena dapat menghasilkan produk dengan harga per unit yang rendah. Sedangkan menurut Dewi dan Wirajaya (2013) Ukuran perusahaan adalah peningkatan dari kenyataan bahwa perusahaan besar akan memiliki kapitalisasi pasar yang besar, nilai buku yang besar dan laba yang tinggi. Sedangkan pada perusahaan kecil akan memiliki kapitalisasi pasar yang kecil, nilai buku yang kecil dan laba yang rendah. Besar kecilnya suatu perusahaan dengan berbagai cara perhitungannya antara lain: total asset,Ln total aset, log size nilai pasar saham, jumlah karyawan dan lain-lain.

\subsection{Nilai Perusahaan}

Menurut Sartono (2011), nilai perusahaan yaitu tujuan memaksimumkan kemakmuran pemegang saham ditempuh dengan memaksimumkan nilai sekarang atau present value, Semua keuntungan pemegang saham akan meningkat apabila harga saham yang dimiliki meningkat. Namun dalam penelitian ini penulis hanya akan menggunakan rasio Price to Book Value (PBV). Menurut Fahmi (2012: 139) "Price to Book Value (PBV) adalah rasio yang membandingkan antara market price per share (nilai saham per lembar) terhadap book value per share (nilai buku per lembar)".

$$
\text { Price to Book Value }(\mathrm{PBV})=\frac{\text { Harga Saham Per Lembar }}{\text { Nilai Buku Per Lembar }}
$$

\subsection{Kerangka Pikir}

\section{Gambar 2.1}

Skematik Kerangka Pikir

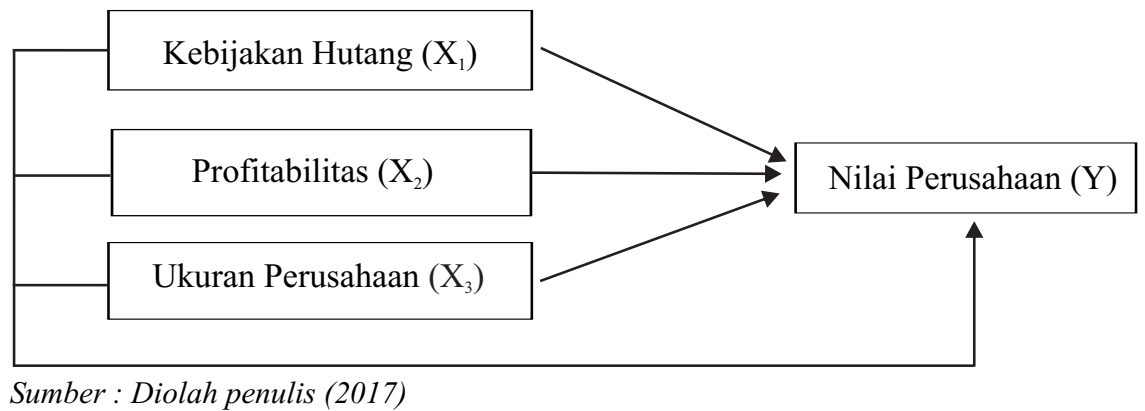

\subsection{Hipotesis}

Berdasarkan beberapa kajian teoritis yang telah di kemukakan, berikut ini hipotesis-hipotesis dalam penelitian ini sebagai berikut :

\section{Hipotesis 1}

$\mathrm{H}_{0}$ 1: Diduga terdapat pengaruh signifikan antara Kebijakan Hutang terhadap Nilai Perusahaan.

$\mathrm{H}_{0}$ 2: Diduga terdapat pengaruh signifikan antara Profitabilitas terhadap Nilai Perusahaan.

$\mathrm{H}_{0} 3$ : Diduga terdapat pengaruh signifikan antara Ukuran Perusahaan terhadap Nilai Perusahaan.

$\mathrm{H}_{0} 4$ : Diduga terdapat pengaruh signifikan secara bersama-sama antara Kebijakan Hutang, Profitabilitas, dan Ukuran Perusahaan terhadap Nilai Perusahaan. 


\section{Metodologi Penelitian}

\subsection{Metode Penelitian}

Metode penelitian menurut Sugiyono (2013), merupakan cara ilmiah untuk mendapatkan data yang valid dengan tujuan dapat ditemukan, dibuktikan dan dikembangkan suatu pengetahuan sehingga pada gilirannya dapat digunakan untuk memahami, memecahkan dan mengantisipasi masalah. Analisis kuantitatif menurut Sugiyono (2012), metode yang dapat diartikan sebagai metode analisis yang berlandaskan pada filsafat positifisme, digunakan untuk meneliti pada populasi dan sampel tertentu, pengumpulan data menggunakan instrument penelitian, analisis data bersifat statistik dengan tujuan untuk menguji hipotesis yang telah ditetapkan.

\subsection{Populasi Dan Sampel}

\subsubsection{Populasi}

Menurut Sugiyono (2013), populasi adalah wilayah generalisasi yang terdiri atas objek/subjek yang mempunyai kualitas dan karakteristik tertentu yang ditetapkan oleh peneliti untuk dipelajari dan kemudian ditarik kesimpulannya. Populasi dari penelitian ini adalah perusahaan manufaktur sub sektor food and beverage yang tercatat di Bursa Efek Indonesia (BEI). Penelitian ini menggunakan periode penelitian 2011-2015 sebanyak 10 perusahaan, dengan jumlah sampel 50 perusahaan.

\subsubsection{Sampel}

Menurut Sugiyono (2013), sampel yaitu bagian dari jumlah dan karakteristik yang dimiliki oleh populasi tersebut. Teknik pengambilan sampel dalam penelitian ini adalah teknik purposive sampling. Menurut Sugiyono (2013) purposive sampling adalah teknik pengambilan sampel sumber data dengan pertimbangan tertentu. Pertimbangan tertentu ini, misalnya orang tersebut yang dianggap paling tahu tentang apa yang kita harapkan, atau mungkin dia sebagai penguasa sehingga akan memudahkan peneliti menjelajahi objek atau situasi sosial yang diteliti. Adapun kriteria yang digunakan untuk memilih sampel adalah sebagai berikut:

1. Perusahaan manufaktur sub sektor food and beverage yang terdaftar di Bursa Efek Indonesia (BEI) periode 2011-2015.

2. Perusahaan manufaktur sub sektor food and beverage yang mempublikasikan laporan keuangan dan annual report (laporan tahunan) selama periode 2011-2015.

3. Laporan keuangan dipublikasikan menggunakan satuan rupiah dalam penyajiannya.

4. Data yang tersedia lengkap (data secara keseluruhan tersedia pada publikasi periode 31 Desember 2011-2015).

\subsection{Teknik Pengumpulan Data}

Data yang dikumpulkan dalam penelitian ini adalah jenis data sekunder, berupa laporan keuangan dan laporan tahunan perusahaan. Sumber data yang digunakan adalah data sekunder. Data sekunder merupakan sumber yang tidak langsung memberikan data kepada pengumpul data, misalnya lewat orang lain atau lewat dokumen. Sugiyono, (2012). Selain itu, data yang digunakan dalam penelitian ini didapatkan dari jurnal, penelitian terdahulu, literatur-literatur dan buku pustaka yang berkaitan, serta materi-materi yang berkaitan yang bisa didapatkan melalui jasa internet.Data yang digunakan dalam penelitian ini adalah data panel. Data panel adalah gabungan antara data runtut waktu (time series) dan data silang (cross section).

\subsection{Teknik Analisis Data}

Dalam penelitian ini digunakan regresi data panel karena tujuan dari penelitian ini adalah untuk menganalisis faktor-faktor apa saja yang mempengaruhi nilai perusahaan antar perusahaan (cross section) dan antar waktu (time series) pada sub-sektor transportasi. Terdapat beberapa metode yang 
biasa digunakan untuk mengestimasi model regresi dengan data panel, diantaranya yaitu:

1. Pendekatan common effect

Pendekatan ini hanya mengkombinasikan data time series dan cross section tanpa melihat perbedaan antar waktu dan perusahaan. Dalam pendekatan yang tidak memperhatikan dimensi perusahaan maupun waktu ini bisa menggunakan metode OLS (Ordinary Least Square) untuk mengestimasi model data panel.

2. Pendekatanfixed effect

Pendekatan ini mengestimasi data panel menggunakan variabel dummyuntuk menangkap adanya perbedaan intercept. Fixed effect ini didasarkan adanya perbedaan intercept antar individu, namun intercept-nya sama antar waktu (time invariant). Disamping itu, model ini juga mengasumsikan bahwa koefisien regresi (slope) tetap antar individu dan waktu.

3. Pendekatan random effect

Dimasukkannya variabel dummy di dalam model fixed effect bertujuan untuk mewakili ketidaktahuan model yang sebenarnya. Namun ini juga membawa konsekuensi berkurangnya derajat kebebasan (degree of freedom) yang pada akhirnya mengurangi efisiensi parameter. Masalah ini bisa diatasi dengan menggunakan variabel gangguan (error terms) yang dikenal dengan metode random effect.

\section{Hasil Dan Pembahasan}

\subsection{Statistik Deskriptif}

Model regresi data panel dengan eviews terdapat 3 macam yang umum digunakan para peneliti yaitu Common Effect Model, Fixed Effect Model dan Random Effect Model. Dalam penelitian ini, pengolahan data menggunakan metode cross-sectional weight untuk menghilangkan adanya heterokedastisitas. Analisis data panel dengan metode cross sectional weight dapat dilakukan dengan beberapa pendekatan yaitu: common effect model dan fixed effect model. Untuk menentukan pendekatan mana yang terbaik, maka harus dilakukan uji chow. Berikut ini adalah hasil perhitungan dengan menggunakan fixed effect model: Perusahaan-perusahaan yang masuk sebagai sampel dapat dilihat pada tabel 4.1.

Tabel 4.1

Statistik Deskriptif

\begin{tabular}{|l|c|c|c|c|}
\hline & PBV & DER & ROA & SIZE \\
\hline Mean & 0.167877 & 0.963615 & 0.133306 & 28.63784 \\
\hline Median & 0.121056 & 1.028725 & 0.096941 & 28.22009 \\
\hline Maximum & 0.562033 & 3.028644 & 0.657201 & 32.15098 \\
\hline Minimum & 0.018847 & 0.046496 & 0.027898 & 26.09035 \\
\hline Std. Dev. & 0.154900 & 0.595870 & 0.121415 & 1.632732 \\
\hline Skewness & 0.978666 & 0.905066 & 2.279782 & 0.664431 \\
\hline Kurtosis & 2.930764 & 4.770258 & 8.828710 & 2.553116 \\
\hline & & & & \\
\hline Jarque-Bera & 7.991544 & 13.35499 & 114.0906 & 4.094959 \\
\hline Probability & 0.018393 & 0.001259 & 0.000000 & 0.129060 \\
\hline & & & & \\
\hline Sum & 8.393839 & 48.18077 & 6.665302 & 1431.892 \\
\hline Sum Sq. Dev. & 1.175710 & 17.39800 & 0.722341 & 130.6249 \\
\hline & & & & \\
\hline Observations & 50 & 50 & 50 & 50 \\
\hline
\end{tabular}

Sumber: Output EViews, diolah oleh penulis (2017) 
Berdasarkan tabel 4.1 diketahui bahwa terdapat empat variabel penelitian yaitu ( $P B V, D E R, R O A$ dan Size) dengan jumlah sampel secara keseluruhan 50 sampel. Dari tabel diatas melalui pengujian statistik deskriptif, dapat disimpulkan bahwa rata-rata nilai perusahaan yang terdaftar di BEI pada periode 2011-2015 adalah 0.167877 dimana nilai standar deviasi adalah 0.154900. Dengan nilai tertinggi 0.562033 da terendah 0.018847 , nilai perusahaan tertinggi dimiliki oleh PT. Sekar Laut Tbk pada tahun 2011 dan terendah dimiliki oleh PT. Delta Djakarta Tbk pada tahun 2015. Kebijakan hutang yang dihitung dengan $D E R$ diketahui rata-rata kebijakan hutang perusahaan adalah 0.963615 dengan standar deviasi sebesar 0.595870, dengan nilai tertinggi 3.028644 dan terendah 0.046496 . Nilai tertinggi dimiliki oleh PT. Multi Bintang Indonesia Tbk pada tahun 2014 dan nilai terendah dimiliki oleh PT. Ultrajaya Milk Industry \& Traiding Company Tbk pada tahun 2011. Yang artinya semakin tinggi nilai $D E R$ maka perusahaan lebih banyak menggunakan hutang dalam pendanaannya. Dari tabel diatas diketahui nilai rata-rata profitabilitas yang dihitung dengan $R O A$ adalah sebesar 0.133306 dengan standar deviasi sebesar 0.121415. Dengan nilai tertinggi 0.657201 dan terendah 0.027898. Nilai tertinggi dari PT. Multi Bintang Indonesia Tbk pada tahun 2013 dan nilai terendah dimiliki oleh PT. Sekar Laut Tbk pada tahun 2011. Artinya semakin tinggi nilai $R O A$ maka kinerja perusahaan semakin baik, perusahaan semakin efisien. Dari hasil pengujian, rata-rata perusahaan sudah efisien. Ukuran perusahaan yang di hitung dengan Size yaitu dengan membandingkan memproyeksikan antara LogNatural dari total aset. Dari tabel 4.1 didapat bahwa secara umum ratarata ukuran perusahaan adalah 28.63784 dengan standar deviasi sebesar 1.632732. Dengan nilai tertinggi 32.15035 dan nilai terendah 26.09035. Nilai tertinggi dari PT. Indofood Sukses Makmur Tbk pada tahun 2015 dan nilai terendah dimiliki oleh PT. Sekar Laut Tbk pada tahun 2011.

\subsection{Analisis Model Data Panel}

\subsubsection{Uji Chow}

Uji chow yang menghasilkan nilai probabilitas $\mathrm{F}$ stat lebih kecil dari $\alpha=0.05$ menghasilkan keputusan bahwa metode FEM signifikan dalam menguji data panel, dan sebaliknya. Pemilihan metode data panel untuk seluruh sampel data dengan menggunakan uji chow adalah pada tabel 4.2 berikut:

Tabel 4.2 Rangkuman Hasil Uji Chow

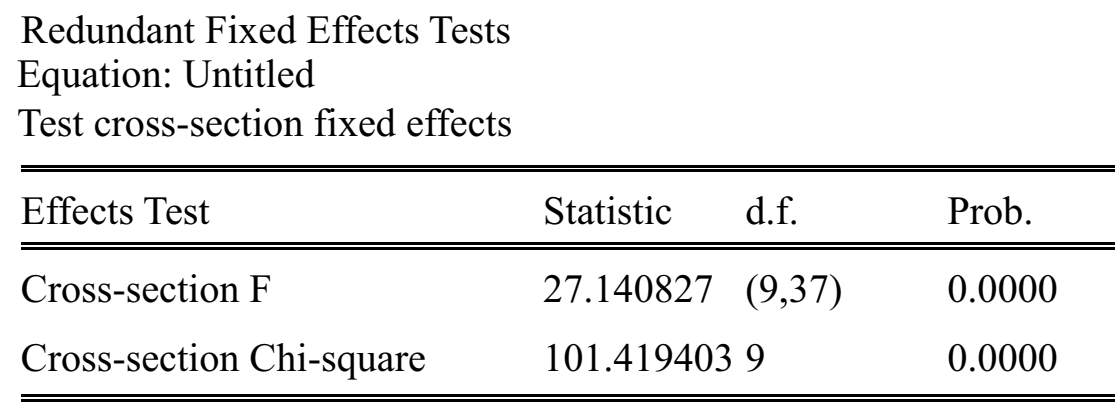

Sumber: Output EViews, diolah oleh penulis (2017)

Berdasarkan tabel 4. 2 nilai Prob $=0,0000$ untuk Cross-section F, yang berarti kurang dari 0.05 Hasil pengujian ini menguatkan dugaan bahwa model untuk seluruh sampel data sebaiknya menggunakan Fixed effect model. Hasil uji Chow yang signifikan dilanjutkan dengan uji Hausmant untuk memilih metode Fixed effect model atau Random Effect model. Berikut hasil uji Hausmant untuk seluruh sampel data: 


\subsubsection{Uji Hausmant}

Tabel 4.3. Rangkuman Hasil Uji Hausmant

Correlated Random Effects - Hausman Test

Equation: Untitled

Test cross-section random effects

\begin{tabular}{|c|c|c|c|}
\hline Test Summary & Chi-Sq. Statistic & Chi-Sq. d.f. & Prob. \\
\hline Cross-section random & 5.127808 & 3 & 0.1627 \\
\hline
\end{tabular}

Sumber: Output EViews, diolah oleh penulis (2017)

Berdasarkan tabel 4.3 nilai Prob $=0.1627$ untuk Cross-section F, yang berarti lebih dari 0.05. Hasil pengujian ini menguatkan dugaan bahwa model untuk seluruh sampel data sebaiknya menggunakan random effect model. Dikarenakan hasil dari uji chow dan uji hausmant tidak konsisten (sama), maka langkah yang selanjutnya harus dilakukan adalah uji LM (Lagrange Multiplier).

Tabel 4.4. Rangkuman Hasil Uji LM (Lagrange Multiplier)

Lagrange Multiplier Tests for Random Effects

Null hypotheses: No effects

Alternative hypotheses: Two-sided (Breusch-Pagan) and one-sided (all others) alternatives

\begin{tabular}{llll}
\hline \hline & \multicolumn{2}{l}{ Test Hypothesis } \\
& Cross-section & Time & Both \\
\hline \hline Breusch-Pagan & 48.60389 & 0.072101 & 48.67599 \\
& $(0.0000)$ & $(0.7883)$ & $(0.0000)$ \\
Honda & 6.971649 & -0.268516 & 4.739831 \\
& $(0.0000)$ & $(0.6058)$ & $(0.0000)$ \\
King-Wu & 6.971649 & -0.268516 & 3.643756 \\
& $(0.0000)$ & $(0.6058)$ & $(0.0001)$ \\
Standardized Honda & 8.952929 & -0.020526 & 2.935144 \\
& $(0.0000)$ & $(0.5082)$ & $(0.0017)$ \\
Standardized King-Wu & 8.952929 & -0.020526 & 1.710378 \\
& $(0.0000)$ & $(0.5082)$ & $(0.0436)$ \\
Gourieroux, et al.* & -- & -- & 48.60389 \\
& & & $(0.0000)$ \\
\hline \hline
\end{tabular}

Sumber: Output EViews, diolah oleh penulis (2017)

Dikarenakan nilai p-value Breusch Pagan pada uji LM diatas $<0.05$ hal ini membuktikan bahwa metode Random Effect lebih baik daripada metode fixed effect.

\subsubsection{Regresi dengan Model Random Effect.}

Berdasarkan hasil uji Uji Chow, Uji Hausman, dan uji LM tersebut maka dilakukan analisis regresi panel data yang fokus ke model Random Efect. Hasil regresi data panel dengan menggunakan Eviews 9.0 memakai metode pendekatan Random Effect dapat dilihat pada tabel berikut pada tabel 4.5. Dari hasil uji regresi random effect pada tabel 4.5 diatas dapat disimpulkan bahwa nilai konstanta adalah 
Tabel 4.5

Hasil Uji Regresi dengan Model Random Effect

\begin{tabular}{|c|c|c|c|c|}
\hline \multicolumn{5}{|c|}{$\begin{array}{l}\text { Dependent Variable: } Y \\
\text { Method: Panel EGLS (Cross-section random effects) } \\
\text { Date: } 05 / 07 / 17 \text { Time: } 20: 35 \\
\text { Sample: } 20112015 \\
\text { Periods included: } 5 \\
\text { Cross-sections included: } 10 \\
\text { Total panel (balanced) observations: } 50 \\
\text { Swamy and Arora estimator of component variances }\end{array}$} \\
\hline Variable & Coefficient & Std. Error & t-Statistic & Prob. \\
\hline $\begin{array}{l}\text { PBV } \\
\text { DER } \\
\text { ROA } \\
\text { SIZE }\end{array}$ & $\begin{array}{l}1.741479 \\
-0.021404 \\
-0.244224 \\
-0.053091\end{array}$ & $\begin{array}{l}0.387151 \\
0.018768 \\
0.111733 \\
0.013461\end{array}$ & $\begin{array}{l}4.498190 \\
-1.140479 \\
-2.185783 \\
-3.944008\end{array}$ & $\begin{array}{l}0.0000 \\
0.2600 \\
0.0340 \\
0.0003\end{array}$ \\
\hline \multicolumn{5}{|c|}{ Effects Specification } \\
\hline $\begin{array}{l}\text { Cross-section random } \\
\text { Idiosyncratic random }\end{array}$ & & & $\begin{array}{l}0.099035 \\
0.038994\end{array}$ & $\begin{array}{l}0.8658 \\
0.1342\end{array}$ \\
\hline \multicolumn{5}{|c|}{ Weighted Statistics } \\
\hline $\begin{array}{l}\text { R-squared } \\
\text { Adjusted R-squared } \\
\text { S.E. of regression } \\
\text { F-statistic } \\
\text { Prob(F-statistic) }\end{array}$ & $\begin{array}{l}0.293461 \\
0.247382 \\
0.039886 \\
6.368689 \\
0.001058\end{array}$ & \multicolumn{2}{|c|}{$\begin{array}{l}\text { Mean dependent var } \\
\text { S.D. dependent var } \\
\text { Sum squared resid } \\
\text { Durbin-Watson stat }\end{array}$} & $\begin{array}{l}0.029113 \\
0.045976 \\
0.073180 \\
0.692330\end{array}$ \\
\hline \multicolumn{5}{|c|}{ Unweighted Statistics } \\
\hline $\begin{array}{l}\text { R-squared } \\
\text { Sum squared resid }\end{array}$ & $\begin{array}{l}0.500326 \\
0.587472\end{array}$ & \multicolumn{2}{|c|}{$\begin{array}{l}\text { Mean dependent var } \\
\text { Durbin-Watson stat }\end{array}$} & $\begin{array}{l}0.167877 \\
0.086242\end{array}$ \\
\hline
\end{tabular}

Sumber: Output EViews, diolah oleh penulis (2017)

1.741479 sedangkan koefisien kebijakan hutang (DER), profitabilitas (ROA) dan ukuran perusahaan (Size) masing-masing -0.021404; -0.244224 dan -0.053091 dengan tingkat signifikansi yang digunakan adalah $5 \%$.

\subsection{Uji Asumsi Klasik}

\subsubsection{Uji Multikolinearitas}

Tabel 4.6

Tabel Uji Multikolinearitas

\begin{tabular}{|c|c|c|c|}
\hline & DER & ROA & SIZE \\
\hline DER & 1.000000 & 0.080098 & -0.033782 \\
\hline ROA & 0.080098 & 1.000000 & -0.149296 \\
\hline SIZE & -0.033782 & -0.149296 & 1.000000 \\
\hline \multicolumn{5}{|l}{ Sumber: Output EViews, diolah oleh penulis (2017) }
\end{tabular}

\subsubsection{Uji Heteroskedastisitas}

Untuk menguji adanya heterokedastisitas, pada penelitian ini, peneliti menggunakan uji Wald. Prosedur uji ini dilakukan dengan mengabsolutkan residu dari hasil regresi yang telah dilakukan. Oleh karena model regresi yang kita pakai adalah model fixed effect, maka residu dari fixed effect yang peneliti pakai dalam hal ini. Setelah itu, residu yang diabsolutkan tadi diregresikan dengan semua variabel independen. 
Tabel 4.7.

Hasil Uji Heteroskedatisitas

Wald Test:

Equation: Untitled

\begin{tabular}{lccc}
\hline \hline Test Statistic & Value & Df & Probability \\
\hline \hline t-statistic & -1.140479 & 46 & 0.2600 \\
F-statistic & 1.300691 & $(1,46)$ & 0.2600 \\
Chi-square & 1.300691 & 1 & 0.2541 \\
\hline
\end{tabular}

Null Hypothesis: $\mathrm{C}(2)=0$

Null Hypothesis Summary:

\begin{tabular}{llc}
\hline \hline Normalized Restriction $(=0)$ & Value & Std. Err. \\
\hline \hline C(2) & -0.021404 & 0.018768
\end{tabular}

Restrictions are linear in coefficients.

Sumber: Output EViews, diolah oleh penulis (2017)

\subsection{Uji Hipotesis}

\subsubsection{Uji Statistik t (Uji Parsial)}

Tabel 4.8

Rangkuman Hasil Uji t

\begin{tabular}{crrrr} 
Variable & Coefficient & Std. Error & t-Statistic & Prob. \\
\hline \hline C & 1.741479 & 0.387151 & 4.498190 & 0.0000 \\
DER & -0.021404 & 0.018768 & -1.140479 & 0.2600 \\
ROA & -0.244224 & 0.111733 & -2.185783 & 0.0340 \\
SIZE & -0.053091 & 0.013461 & -3.944008 & 0.0003 \\
\hline
\end{tabular}

Sumber: Output EViews, diolah oleh penulis (2017)

Berdasarkan tabel 4.8 di atas, berikut penjelasan masing-masing hipotesa yang telah ditentukan sebelumnnya dalam Bab II, dari tabel diatas dapat diketahui bahwa:

1. Nilai t-stat untuk kebijakan hutang $(D E R)$ adalah sebesar -1.140479. Hal ini menunjukkan bahwa $\mathrm{t}$-stat $<\mathrm{t}_{\text {tabel }}$ dengan nilai p-value atau tingkat siginifikansi sebesar $0.2600>0,05$ dapat disimpulkan $\mathrm{H}_{02}$ diterima atau $\mathrm{H}_{\mathrm{al}}$ ditolak. Artinya $D E R$ tidak berpengaruh siginifikan terhadap nilai perusahaan.

2. Pengujian selanjutnya diketahui nilai t-stat untuk Profitabilitas $(R O A)$ adalah sebesar 2.185783. Hal ini menunjukan bahwa $\mathrm{t}$-stat $<\mathrm{t}_{\text {tabel }}$ dengan nilai $\mathrm{p}$-value atau tingkat signifikansi sebesar $0.0340<0,05$. Dengan hasil tersebut dapat disimpulkan $\mathrm{H}_{02}$ ditolak atau $\mathrm{H}_{\text {a2 }}$ diterima. Artinya $R O A$ berpengaruh negatif dan signifikan terhadap nilai perusahaan.

3. Pengujian selanjutunya diketahui nilai t-stat untuk Size adalah sebesar -3.944008. Hal ini menunjukan bahwa $\mathrm{t}$-stat $<\mathrm{t}_{\text {tabel }}$ dengan nilai p-value atau tingkat signifikansi sebesar $0.0003<$ 0,05. Dengan hasil hasil tersebut dapat disimpulkan $\mathrm{H}_{03}$ ditolak atau $\mathrm{H}_{\mathrm{az}}$ diterima. Artinya ukuran perusahaan (Size) berpengaruh negatif dan signifikan terhadap nilai perusahaan. 


\subsubsection{Uji Statistik F (Uji Simultan)}

Tabel 4.9.

Hasil Uji F

\begin{tabular}{llll}
$\begin{array}{l}\text { Cross-section random } \\
\text { Idiosyncratic random }\end{array}$ & & 0.099035 & 0.8658 \\
& Weighted Statistics & 0.038994 & 0.1342 \\
\hline \hline & 0.293461 & Mean dependent var & 0.029113 \\
R-squared & 0.247382 & S.D. dependent var & 0.045976 \\
Adjusted R-squared & Sum squared resid & 0.073180 \\
S.E. of regression & 0.039886 & Durbin-Watson stat & 0.692330 \\
F-statistic & 6.368689 & & \\
Prob(F-statistic) & 0.001058 & & \\
\hline \hline
\end{tabular}

Sumber: Output EViews, diolah oleh penulis (2017)

Berdasarkan tabel 4.9 di atas, dapat diketahui nilai F-stat sebesar 6.368689. Nilai ini akan dibandingkan dengan nilai $\mathrm{F}_{\text {tabel }}$ sebesar 2,81. Dari nilai-nilai di atas, diketahui nilai $\mathrm{F}$-stat (6.368689) $>\mathrm{F}_{\text {tabel }}(2.81)$. sehingga $\mathrm{H}_{0}$ ditolak dan $\mathrm{H}_{\mathrm{a}}$ diterima, artinya terdapat pengaruh simultan yang signifikan dari kebijakan hutang $\left(\mathrm{X}_{1}\right)$, profitabilitas $\left(\mathrm{X}_{2}\right)$ dan ukuran perusahaan $\left(\mathrm{X}_{3}\right)$ terhadap nilai perusahaan $(Y)$.

\subsubsection{Uji Koefisien Determinasi $\left(R^{2}\right)$}

Nilai Adjusted $R$ Square menunjukan seberapa besar variabel independen mampu menjelaskan varian dari variabel dependen. Berdasarkan tabel 4.9 dapat dilihat hasil analisis regresi secara keseluruhan di mana nilai Adjusted $R$ Square sebesar 0.247382. Hal tersebut menunjukkan bahwa variabel bebas yang terdiri dari kebijakan hutang $(D E R)$, profitabilitas $(R O A)$ dan ukuran perusahaan (Size), hanya mampu menjelaskan nilai perusahaan sebagai variabel terikat sebesar $24,74 \%$. Sisanya, sebesar $75,26 \%$ dipengaruhi oleh variabel lainnya yang tidak diteliti pada penelitian ini.

\section{Simpulan Dan Saran}

Dari lima hipotesis yang diajukan pada bab sebelumnya, maka kesimpulan ysng diperoleh adalah sebagai berikut:

1. Kebijakan hutang (DER) tidak berpengaruh signifikan terhadap nilai perusahaan. Hal ini menjelaskan bahwa dimana tinggi rendahnya hutang tidak mempengaruhi keputusan pemegang saham dalam meningkatkan nilai perusahaan. Maka sebaiknya perusahaan tidak sepenuhnya dibiayai dengan hutang, agar perusahaan tidak menimbulkan kebangkrutan semakin tinggi. Dengan hasil tersebut dapat disimpulkan $\mathrm{Ho}_{1}$ diterima atau $\mathrm{Ha}_{1}$ ditolak.

2. Profitabilitas (ROA) berpengaruh negatif dan signifikan terhadap nilai perusahaan. Hal ini menjelaskan bahwa hasil yang negatif menunjukan bahwa semakin kecil earning power semakin tidak efisien perputaran aset atau semakin kecil profit margin yang diperoleh oleh perusahaan. Nilai signifikan ini diperoleh karena semakin tinggi ROA maka semakin baik produktivitas aset dalam memperoleh keuntungan sehingga akan mempengaruhi nilai perusahaan. Dengan hasil tersebut dapat disimpulkan $\mathrm{H}_{02}$ ditolak atau $\mathrm{H}_{\mathrm{a} 2}$ diterima.

3. Ukuran perusahaan (Size) berpengaruh negatif dan signifikan terhadap nilai perusahaan. Hal ini menjelaskan bahwa ukuran perusahaan yang terlalu besar akan menyebabkan kurangnya efesiensi pengawasan kegiatan operasional dan strategi oleh jajaran manajemen tingkat tinggi, sehingga dapat mengurangi nilai perusahaan. Dengan hasil hasil tersebut dapat disimpulkan $\mathrm{H}_{03}$ ditolak atau $\mathrm{H}_{\mathrm{a} 3}$ diterima.

4. Kebijakan hutang (DER), Profitabilitas (ROA) dan Ukuran perusahaan (Size) secara bersamasama berpengaruh secara signifikan terhadap nilai perusahaan 


\subsection{Saran}

Untuk saran-saran yang diajukan oleh penulis adalah sebagai berikut:

1. Penelitian ini menggunakan perusahaan food and beverage yang terdaftar di BEI. Penelitian selanjutnya disarankan untuk mengambil sampel pada jenis industri lain diluar perusahaan food and beverage karena hanya sedikit perusahaan yang dapat dijadikan sampel sehubungan masih banyak perusahaan food and beverage di Indonesia yang belum mendaftar di BEI.

2. Mengingat adanya keterbatasan dalam penelitian ini, maka bagi peneliti selanjutnya disarankan untuk melakukan perluasan penelitian. Perluasan penelitian yang dimaksud adalah tidak hanya terbatas pada faktor-faktor di dalam laporan keuangan saja, memperluas penelitian dengan cara memperpanjang periode penelitian dengan menambah tahun pengamatan dan juga memperbanyak jumlah sampel untuk penelitian yang akan datang.

3. Penelitian yang akan datang juga sebaiknya menambahkan variabel bebas yang lain yang berpengaruh terhadap nilai perusahaan, selain yang digunakan dalam penelitian ini dan tetap berlandaskan pada penelitian-penelitian sebelumnnya.

\section{Daftar Pustaka}

Dewi Mahatna, Ayu Sri, Dan Wirajaya, Ari. 2013. Pengaruh Struktur Modal, Profitabilitas Dan Ukuran Perusahaan Pada Nilai Perusahaan. E-Jurnal Akuntansi. Universitas Udayana.

Fahmi, Irham. 2011. Analisis Laporan Keuangan. Bandung. Alfabeta. 2012. Pengantar Manajemen Keuangan. Bandung. Alfabeta.

Ghozali, Imam. 2012. Aplikasi Analisis Multivariate dengan Program IBM SPSS 20. Semarang: UNDIP.

Gujarati, D.N. \& D.C. Porter. 2012. Dasar-Dasar Ekonometrika. Buku 2. Jakarta. Salemba Empat. Gujarati, Damodar N. 2012. Dasar-Dasar Ekonometrika. Jakarta. Erlangga. Hanafi, Mamduh M. 2010. Manajemen Keuangan. Edisi Pertama. Yogyakarta. BPFE. Harahap, Sofian Syafri. 2010. Analisis Kritis Atas Laporan Keuangan,. Jakarta. Rajawali Persada. 2011.Teori Akuntansi. Edisi Revisi 2011. Jakarta. Rajawali Pers.

Kasmir. 2012, Analisis Laporan Keuangan. PT.Raja Grafindo Persada. Jakarta. .2013. Pengantar Manajemen Keuangan. Jakarta. Kencana Prenada Media Group.

Munawir, S. 2010. Analisa Laporan Keuangan. Yogyakarta. Liberty. 2012. Analisa Laporan Keuangan. Yogyakarta. Liberty.

Niresh, J. Aloy dan T.Velnampy. 2014. Firm Size and Profitability: A Study of Listed Manufacturing Firmsin Sri Lanka. International Journal of Business and Management. Vo1 9(4)

Sartono, Agus. 2010. Manajemen Keuangan Teori danAplikasi. Yogyakarta. BPFE.

Sawir, Agnes. 2013. Analisis Kinerja Keuangan dan Perencanaan Keuangan. Jakarta. PT Gramedia Pustaka Umum.

Sugiyono. 2012. Memahami Penelitian Kualitatif. Bandung. Penerbit Alfabeta. . 2013. Metode Penelitian Kuantitatif Kualitatif Dan R\&D. Cetakan ke-19. Bandung. Alfabeta.

Sukrini, Dewi. 2012. Kepemilikan Manajerial, Kepemilikan Institusional, Kebijakan Dividen Dan Kebijakan Hutang Terhadap Nilai Perusahaan. Accounting Analysis Journal.

Susanto, Azhar. 2013. Sistem Informasi Akuntansi. Bandung. Lingga Jaya.

Sutrisno. 2012. Manajemen Keuangan Teori, Konsep Dan Aplikasi. Edisi Kedelapan. Yogyakarta. Ekonesia.. 